J. Perinat. Med. 17 (1989) 145

\title{
Delivery of the low birthweight and the very low birthweight breech: cesarean section or vaginal delivery?
}

\author{
Joseph S. Suidan and Raja A. Sayegh \\ Department of Obstetrics ad Gynecology, American University Medical Center, \\ Beirut, Lebanon
}

\section{Introduction}

Delivery of the low birthweight breech baby presents a continuing challenge to the obstetrician who must always keep in mind the possibility of entrapment of a relatively large aftercoming fetal head with its sequelae of intracranial hemorrhage and possible neonatal death. This has led various investigators to study the potential of a prophylactic cesarean delivery for improving the neonatal outcome of small breech babies, especially that nowadays, newborns weighing as little as 800 grams or even less are expected to survive with good intensive care. Actually, several reports [2, $3,5,11,12$ in the recent literature have claimed beneficial effects of routine abdominal delivery for the very small breech, while others $[1,4,6,10]$ have failed to show such benefits.

It is the purpose of this investigation to study the potential benefits of cesarean delivery of the small breech baby in a Lebanese population.

\section{Material and methods}

The hospital records of all singleton newborns with birthweights of 2500 grams or less and delivered in the breech presentation at the American University Hospital between January 1, 1977 and December 31, 1984 were reviewed. They were checked for the birthweight, method of delivery, 1-minute and 5-minute APGAR scores, length of hospitalization, and survival at the time of discharge from the neonatal intensive care unit. Newborns with lethal congenital anomalies were excluded. A newborn was considered to have survived only if it was alive at the age of 28 days and if it was discharged from intensive care in a stable condition.

\section{Curriculum vitae}

JoSEPH S. SUIDAN obtained his M.D. degree with distinction from the American University of Beirut in 1979. After his residency training in Obstetrics and Gynecology, he spent two years as a fellow in Maternal-Fetal Medicine at the New York University Medical Center. He joined the faculty of the American

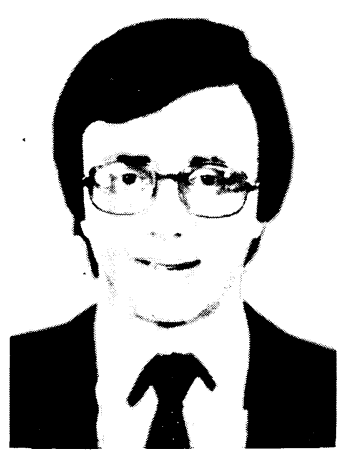
University in 1984, and has recently transferred to St. Joseph University in Beirut to direct the newly established perinatal unit in Hôtel-Dieu Hospital.

The respective maternal records were also reviewed and specifically checked for the indication for a cesarean section whenever applicable, and for the type of obstetrical anesthesia used.

The decision to deliver a particular patient vaginally or abdominally was made by the physician managing that patient purely on obstetrical grounds, and thus was not randomized.

The newborns were classified into two weight groups: $1000-1750$ grams, and 7151-1500 grams. Babies weighing less than 1000 grams at birth were excluded because of poor survival. The cutoff point of 1750 grams was suggested by our preliminary analysis of the results using birthweight brackets of 250 grams. In each of the two weight groups, babies delivered by cesarean section were compared to babies delivered vaginally with respect to survival, APGAR scores, and 
length of hospitalization. Statistical analysis was done using the chi-square test and the Student's t-test, and statistical significance was defined at the 0.05 level.

\section{Results}

A total of 199 sigleton breeches were delivered during the period of the study. 71 had a birghweight between 1000 and 1750 grams, and 128 had a birthweight between 1751 and 2500 grams. 90 were delivered by cesarean section and 109 were delivered vaginally. All cesarean sections were done under general anesthesia, and the great majority of vaginal deliveries were done under epidural anesthesia. Indications for cesarean section were: previous cesarean section, small pelvis, cord prolapse, fetal distress, preeclampsia, placenta preiva, and fottling breech presentation. Very few cesarean sections were done solely for a premature breech as an indication.

Table I shows that in the birghweight group of $1000-1750$ grams, breeches who were delivered abdominally had a significantly higher survival rate than those who were delivered vaginally. However, in the birthweight group of $1751-2500$ grams, breeches delivered by cesarean section and those delivered vaginally had similar survival rates.

The 1-minute and 5-minute APGAR scores and the length of hospitalization were not significantly different between the two methods of delivery in either birghweight range (tables II and III).

Table I. Survival rates of low birthweight breeches.

\begin{tabular}{|c|c|c|c|}
\hline \multirow[t]{2}{*}{ Birthweight } & \multicolumn{2}{|l|}{ Survival rate } & \multirow{2}{*}{$\begin{array}{l}\mathrm{p} \text { value } \\
\text { (Chi-square test) }\end{array}$} \\
\hline & Cesarean section & Vaginal delivery & \\
\hline $\begin{array}{l}1000-1750 \text { grams } \\
1751-2500 \text { grams }\end{array}$ & $\begin{array}{l}20 / 27=74 \% \\
58 / 63=92 \%\end{array}$ & $\begin{array}{l}16 / 44=36 \% \\
57 / 65=88 \%\end{array}$ & $\begin{array}{c}<0.01 \\
\text { NS }\end{array}$ \\
\hline
\end{tabular}

$\mathrm{NS}=$ not significant

Table II. APGAR scores of low birthweight breeches.

\begin{tabular}{lccl}
\hline Birthweight & Cesarean section & Vaginal delivery & p value (t-test) \\
\hline 1000-1750 grams & $\mathrm{n}=27$ & $\mathrm{n}=44$ & \\
1-minute APGAR score & $3.4 \pm 1.8$ & $3.6 \pm 2.2$ & $\mathrm{NS}$ \\
5-minute APGAR score & $6.1 \pm 1.9$ & $5.9 \pm 2.7$ & $\mathrm{NS}$ \\
1751 -2500 grams & $\mathrm{n}=63$ & $\mathrm{n}=65$ & \\
1-minute APGAR score & $5.4 \pm 2.2$ & $5.6 \pm 2.3$ & $\mathrm{NS}$ \\
5-minute APGAR score & $7.6 \pm 1.4$ & $7.5 \pm 2.2$ & $\mathrm{NS}$ \\
\hline
\end{tabular}

Results are shown as mean \pm standard deviation

$\mathrm{NS}=$ not significant

Table III. Length of hospitalization in neonatal intensive care of surviving low birthweight breeches.

\begin{tabular}{lccc}
\hline Birthweight & Cesarean section & Vaginal delivery & $\mathrm{p}$ value (t-test) \\
\hline 1000-1750 grams & $\mathrm{n}=20$ & $\mathrm{n}=16$ & \\
Days in hospital & $49 \pm 16$ & $52 \pm 21$ & $\mathrm{NS}$ \\
$1751-2500$ grams & $\mathrm{n}=48$ & $\mathrm{n}=57$ & \\
Days in hospital & $14 \pm 17$ & $11 \pm 14$ & $\mathrm{NS}$ \\
\hline
\end{tabular}

Results are shown as mean \pm standard deviation

$\mathrm{NS}=$ not significant 


\section{Discussion}

The major questions that one should attempt to answer when dealing with a small breech in labor are whether there is a significant improvement in neonatal outcome with prophylactic cesarean delivery, and whether such an improvement, if it exists, is of sufficient magnitude to justify the resulting higher rate of cesarean sections. Until now, no final answers to these questions are available. Several studies $[7,8,9,13,14,15]$ have reported a more favorable outcome of breeches weighing less than 1500 grams with abdominal delivery, whereas others $[1,4,6,10]$ have found no differences in outcome between vaginal and abdominal delivery. Our own results are in line with the former, namely that very small breeches (birthweight $\leqslant 1750$ grams) who are delivered abdominally have a higher chance of survival than the vaginally delivered breeches. It is worth mentioning at this point that our cesarean sections were done prophylactically mostly for patients with a previous cesarean section, and rarely for a premature breech as such. Had prophylactic cesarean section been a routine measure for delivery of the very small breech fetus, we would have expected an even better survival rate because this would obviate the risks of labor in such cases.

The observation that APGAR scores were similar with cesareans and vaginal deliveries may be due to a confounding variable, namely general anesthesia, which is known to be associated with an increased incidence of transient depression at birth. As to the length of hospitalization, we did not find any previous report on this variable in the reviewed literature. Our results reveal a slight in the reviewed literature. Our results reveal a slight but not significant tendency to a shorter hospital stay of survivors who were delivered abdominally in the weight group of $1000-1750$ grams (table III). However, the numbers are too small to allow us to draw any firm conclusions about the length of the hospital stay. Nevertheless, it may be useful to study this variable in future cost-benefit analyses, especially if the high costs of neonatal intensive care are taken into consideration.

It is noteworthy that our cesarean section rate was $38 \%$ in the $1000-1750$ gram babies, whereas it was $49 \%$ in the $1751-2500$ gram babies. This reflects the general attitude of our obstetricians towards the very low birthweight baby, and their reluctance to perform an "unnecessary" cesarean section for a very small baby who, in their belief, is likely to succumb to the sequelae of severe prematurity. Fortunately, with recent advances in neonatal intensive care, this attitude is changing and obstetricians are becoming more aggressive in their attempts to salvage the very small baby.

In conclusion, our findings support the hypothesis that prophylactic abdominal delivery of the very low birthweight breech offers a better chance of survival than vaginal delivery. Obviously, this would apply only if the fetus does not have a lethal congenital anomaly. Bearing in mind that breech babies have a higher incidence of congenital anomalies than vertex babies [10], the role of a detailed sonographic assessment becomes crucial in the management of the low birthweight breech. Ultrasound here is most helpful in getting an accurate estimate of the fetal weight and in ruling out sonographically detectable major congenital anomalies. Only then would the prerequisites for a prophylactic cesarean delivery by fulfilled.

\begin{abstract}
We studied neonatal survival rates, APGAR scores, and length of hospital stay in 199 singleton breeches weighing $1000-2500$ grams at birth. We found that in the birthweight range of $1000-1750$ grams, breeches who were delivered by cesarean section had a significantly higher survival rate $(74 \%)$ than those who were delivered vaginally $(36 \%, \mathrm{p}<0.01)$. however, in the birthweight range of $1751-2500$ grams, there was no significant
\end{abstract}

difference in the survival rates between breeches delivered abdominally and those delivered vaginally. The 1minute and the 5-minute APGAR scores and the length of the hospital stay were not significantly different between the abdominal and the vaginal delivery groups in either birthweight range. The data indicate that the very low birthweight breech ( $\leqslant 1750$ grams) may benefit from a prophylactic cesarean section.

Keywords: Breech presentation, infant, low birthweight, low birghweight breech, premature breech, very low birthweight breech. 


\section{Zusammenfassung}

Entbindung von untergewichtigen und stark untergewichtigen Steißlagen: per Sectio oder vaginal?

Es herrscht immer noch kein Konsens hinsichtlich der idealen Methode zur Entbindung eines untergewichtigen Kindes mit Steißlage. Einige Autoren favorisieren routinemäßig die abdominale Schnittentbindung, während andere empfehlen, eine vaginale Entbindung zu versuchen. In der vorliegenden Studie untersuchten wir das unterschiedliche neonatale Outcome bei vaginal entwikkelten und bei per Sectio entbundenen untergewichtigen Steißlagen. Wir berichten über 199 Neugeborene mit einem Geburtsgewicht zwischen 1000 und $2500 \mathrm{~g}$, die in einem Zeitraum von 8 Jahren nach Einlingsgraviditäten aus einer Steißlage geboren wurden. Tabelle I zeigt, daß bei einem Geburtsgewicht zwischen 1000 und $1750 \mathrm{~g}$ per Sectio entbundene Steißlagen eine significant höhere Überlebensrate haben als vaginal entwickelte Kinder $(74 \%$ vs. $36 \%, p<0.01)$. Bei einem Geburtsgewicht zwischen 1751 und $2500 \mathrm{~g}$ hatten per Sectio entbundene und vaginal entwickelte Steißlagen jedoch vergleichbare Überlebensraten ( $92 \%$ bzw. $88 \%$ ). In beiden Gewichtsklassen gab es hinsichtlich des APGAR-Scores nach einer bzw. nach fünf Minuten und der Länge des stationären Aufenthaltes keine signifikanten Unterschiede zwischen abdominal und vaginal entbundenen Kindern (Tablellen II und III).

Unsere Ergebnisse zeigen, daß stark untergewichtige Steißlagen $(\leqslant 1750 \mathrm{~g})$ eine bessere Überlebenschance ha- ben, wenn eine abdominale Schnittentbindung vorgenommen wird. Bei einem Geburtsgewicht von mehr als $1750 \mathrm{~g}$ sind die Überlebenschancen bei vaginaler und abdominaler Entbindung vergleichbar. Damit stimmen wir mit in der Literatur beschriebenen Ergebnissen überein, jedoch liegt unser Cutoff-Point mit $1750 \mathrm{~g}$ etwas höher als der in anderen Studien angesetzte Grenzwert von $1500 \mathrm{~g}$. Die Beobachtung, daß bei beiden Entbindungsmodi vergleichbare APGAR-Scores resultieren, ist möglicherweise auf die Vollnarkose zurückzuführen, in der die Sectio durchgeführt wird und die mit einer erhöhten Inzidenz von passageren Depressionen unmittelbar post partum einhergeht. Die geringe, wenn auch nicht signifikante Tendenz zu einem kürzeren stationären Aufenthalt von per Sectio entbundenen Kindern in der Gewichtsklasse 1000-1750 g hat eine gewisse Bedeutung im Hinglick auf Kosten-Nutzen-Analysen (Tabelle III).

Wir schlußfolgern, daß die prophylaktische Schnittentbindung der stark untergewichtigen Steißlage die Überlebenschance erhöht und der vaginalen Entwicklung vorzuziehen ist. Bevor man sich jedoch zu einer Sectio entscheidet, sollte das fetale Gewicht möglichst genau geschätzt werden und letale congenitale Anomalien ausgeschlossen werden, da in diesem Fall jegliches aggressive Vorgehen nutzlos ist. Dies unterstreicht die Bedeutung einer genauen sonographischen Untersuchung bei einer untergewichtigen Steißlage vor einem Eingriff.

Schlüsselwörter: Kinder mit niedrigem Geburtsgewicht, Steißlage, Steißlagen mit niedrigem und sehr niedrigem Geburtsgewicht, Steißlage und Frühgeburt.

\section{Résumé}

Accouchement des sièges de petits et de très petits poids de naissance: césarienne ou voie basse?

Il n'y a pas encore de consensus sur la méthode idéale d'accouchement des sièges de faible poids de naissance, certains préconisent une césarienne systématique, alors que d'autres recommendent un essai de voie basse. Ce travail vise à étudier les différences de l'évolution néonatale entre les sièges de faible poids de naissance nés par voie basse et ceux nés par césarienne. Nous avons repris les dossiers de 199 nouveaux-nés uniques pesant 1000 à 2500 grammes nés en présentation du siège sur une période de huit années consécutives. Le tableau I montre que les sièges de poids de naissance de 1000 à 1750 grammes nés par césarienne ont un taux de survie significativement plus élevé (74\%) que ceux qui sont nés par voie basse $(36 \%, p<0,01)$. Toutefois pour les sièges de poids de naissance de 1751 à 2500 grammes, le taux de surivie est similaire pour ceux qui sont nés par césariennes ou par voie basse (respectivement $92 \%$ et $88 \%$ ). Les scores d'Apgar à 1 et à 5 minutes ainsi que la durée d'hospitalisation ne sont pas significativement différents entre les 2 groupes quels que soient les poids de naissance (tableaux II et III).
Nos données indiquent que les sièges de très pettits poids de naissance ( $₹ 1750$ grammes) ont de meilleures chances de survie après césarienne qu'après accouchement par voie basse. Néanmoins, les sièges de poids supérieur par voie basse. Néanmoins, les sièges de poids supérieur à 1750 grammes ont autant de chances par voie basse que par césarienne. Cela est en accord avéc certaines publications qui se sont intéressées à ce sujet dans la littérature, bien que notre limite de 1750 grammes soit légèrement supérieure à la limite plus habituelle de 1500 grammes trouvée dans d'autres études. L'observation de scores d'Apgar similaires quel que soit le mode d'accouchement peut être secondaire au fait que l'anesthésie générale, utilisée pour toutes les césariennes, s'accompagne d'une élévation de l'incidence des dépressions transitoires à la naissance. La légère tendance, bien que non significative, à une durée d'hospitalisation plus brève pour les survivants nés par césarienne dans le groupe de poids de 1000 à 1750 grammes (tableau III) souligne l'importance relative de l'inclusion de cette variable dans les analyses futures de couts-bénéfices.

Nous concluons que la césarienne porphylactique chez les sièges de très petits poids de dnaissance offre de 
meilleures chances de survie néonatale que l'accouchement par voie basse. Néanmoins, avant de prendre la décision de césariser, il est impératif d'obtenir une bonne estimation du poids fotal et d'éliminer des malforma- tions congénitales léthales qui rendraient futiles toute approche angressive. C'est souligner le rôle crucial d'un bilan échographique détaillé des sièges de faible poids avant toute intervention.

Mots-clés: Nouveau-né, petit poids de naissance, présentation due siège, siège de petit poids de naissance, siège prématuré, siège de très petit poids de naissance.

\section{References}

[1] Bodmer B, A Benjamin, FH McLean, RH Usher: Has use of cesarean section reduced the risks of delivery in the preterm breech presentation? Am $\mathrm{J}$ Obstet Gynecol 154 (1986) 244

[2] Bowes WA JR, ES TAYLOR, M O'BRIEN, C Bowes: Breech delivery: evaluation of the effect of the method of delivery on perinatal results and maternal morbidity. Am J Obstet Gynecol 135 (1979) 965

[3] Cox C, AC Kendall, M Hommers: Changed prognosis of breech-presenting low birghweight infants. Br J Obstet Gynaecol 89 (1982) 881

[4] Cruikshank D, RM Pitkin: Delivery of the premature breech. Obstet Gynecol 50 (1977) 367

[5] Doyle LW, AL Rickards, GW Ford, RJ PepPerELL, W KITCHEN: Outcome of the very low-birghweight $(500-1,499 \mathrm{~g})$ singleton breech: benefit of caesarean section. Aust NZ J Obstet Gynaecol 25 (1985) 259

[6] EfFer SB, S Saigal, C Rand, DJS Hunter, B STOSKOPF, AC HARPER, C NiMrod, R MiLNER: Effect of delivery on outcome in the very low-birthweight breech infant: is the improved survival related to cesarean section or other perinatal care maneuvers? Am J Obstet Gynecol 145 (1983) 123

[7] Gimovsky ML, RH PeTRIE: The intrapartum and neonatal performance of the low-birth-weight vaginal breech delivery. J Reprod Med 27 (1982) 451

[8] Goldenberg RL, KG Nelson: The premature breech. Am J Obstet Gynecol 127 (1977) 240

[9] Granati B, M Rondinelli, C Capoti, V CarNIELLI, M BotTos, FF Rubaltelli: The premature breech presentation; outcome of newborn infants born by vaginal or abdominal delivery. Am J Perinatol 1 (1984) 145
[10] Karp LE, JR Doney, T McCarthy, PJ Meis, M HALL: The premature breech: trial of labor or cesarean section? Obstet Gynecol 53 (1979) 88

[11] KaupPILA O, M Grönroos, P Aro, P AitToniemi, M KuOPPALA: Management of low birth weight breech delivery: should cesarean section be routine? Obstet Gynecol 57 (1981) 289

[12] MaIn DM, EK MAIN, MM Maurer: Cesarean section versus vaginal delivery for the breech fetus weighing less than 1,5000 grams. Am J Obstet Gynecol 146 (1983) 580

[13] Nisell, H, P Bistoletti, C Palme: preterm breech. Early and late complications. Acta Obstet Gynecol Scand 60 (1981) 363

[14] Viegas OA, I Ingemarsson, LP Sim, K Singh, M Cheng, SS Ratnam, KK Chow, TH Ho, D VenGADASALAM: Collaborative study on preterm breeches: vaginal delivery versus cesarean section. Asia Oceania J Obstet Gynaecol 11 81985) 349

[15] Westgren LM, G Songster, RH Paul: Preterm breech delivery: another retrospective study. Obstet Gynecol 55 (1985) 481

Received November 12, 1988. Accepted December 13, 1988.

Joseph S. Suidan, M.D.

Department of Obstetrics and Gynecology

Hôtel-Dieu Hospital

Beirut, Lebanon 